Article

\title{
Efficient Synthesis of Readily Water-Soluble Sulfonic Acid Carbamates
}

\author{
Krzysztof R. Idzik *, Karsten Nödler and Tobias Licha \\ Department Applied Geology, Geoscience Centre of the University of Göttingen, Goldschmidtstrasse 3, \\ 37077 Göttingen, Germany; E-Mails: karsten.noedler@geo.uni-goettingen.de (K.N.); \\ tobias.licha@geo.uni-goettingen.de (T.L.)
}

* Author to whom correspondence should be addressed; E-Mail: krzysztof.idzik@pwr.wroc.pl; Tel.: +49-551-3912861.

Academic Editor: Derek J. McPhee

Received: 10 March 2015 / Accepted: 8 April 2015 / Published: 16 April 2015

\begin{abstract}
A series of various readily water-soluble carbamates were synthesized with good yields. These compounds are useful chemical tracers for assessing the cooling progress in a georeservoir during geothermal power plant operation. Acylation of primary amines was carried out as well as using a solution of sodium bicarbonate and without the presence of salt. Products were characterized by ${ }^{1} \mathrm{H}-\mathrm{NMR}$ and ${ }^{13} \mathrm{C}-\mathrm{NMR}$. Purity was confirmed through elemental analysis.
\end{abstract}

Keywords: chloroformates; primary amines; carbamates; thermo-sensitive tracers; urethanes

\section{Introduction}

Carbamates play an important role in medicine as biologically active compounds; for example, quer-Cetin-carbamate and Tricine-carbamate are prodrugs [1-3]. These compounds are efficiently transported by the oligopeptide transporter 1 (PepT1), a membrane transport protein localized in the brush-border membranes of intestinal epithelial cells, resulting in significantly enhanced oral bioavailability of the parent drugs [4]. Moreover, studies have revealed that in these compounds, L-amino acid carbamate structural fragments are crucial for enhanced water solubility and cell permeability [5].

Carbamates are also known as urethanes, e.g., ethyl carbamate occurs naturally in many fermented foods and beverages [6-8]. The precursor of ethyl carbamate is also well-known to be genetically 
related to lactic acid bacteria [9]. On the other hand, urethanes as polymers (polyurethanes SPUs) have been utilized in medical devices since the 1960s due to their established biocompatibility, excellent mechanical properties, and extended fatigue life [10], which allows their use in several medical device designs, including but not limited to cardiac pacemaker and neurological lead coatings [11], infusion pumps [12], dialysis catheters [13], vascular grafts [14], intervertebral discs, acetabular cups [15], and arteriovenous shunts [16], where bioresistant materials are critical.

It is also worth mentioning that specific compounds from the class of carbamates are widely used as insecticides and fungicides in agriculture. Their mode of action is in affecting the nervous system by disrupting an enzyme that regulates acetylcholine, a neurotransmitter [17]. These compounds are considered hazardous to the environment and human health. They are on the priority list published by the US Environmental Protection Agency (EPA) [18,19].

As demonstrated, carbamates are used in many different applications. We are interested in this class of compounds because they are potentially useful to investigate the temperature distribution of deep geological formations. Currently, there is an increasing demand for reactive tracers with thermo-sensitive properties for improved reservoir management in geothermal systems with thermal drawdown. Promising tracer candidates are compounds susceptible to undergoing hydrolysis, which are of greater interest for geothermal applications [20,21]. This is mainly caused by the fact that the reservoir temperature is not directly accessible. To estimate the thermal state of a georeservoir, two slightly different thermo-sensitive tracer approaches are currently used. One uses the non-specific thermal decay kinetics of established tracers (e.g., naphthalene sulfonates, fluorescein) at high temperatures while the other approach exploits the structure-related kinetics of defined hydrolysis reactions (e.g., phenol acetates). Up to now, though, successful tracer application has been limited to certain geothermal temperature conditions due to either the non-availability of suitable purchasable substances or the lack of knowledge on structure-dependent kinetics. To fill these gaps and to improve the general applicability of thermo-sensitive tracers, a wide spectrum of hydrolyzable compounds with thermo-sensitive properties was synthesized in our working group. The concept of structure-dependent kinetics learnt from phenolic esters [20] was transferred to carbamates. Their thermally induced hydrolysis leads to well known reaction products with fluorescent properties in a first-order reaction. These novel carbamates with sulfonic groups and thus a desired high water solubility $(>1 \mathrm{~kg} / \mathrm{L})$ differ in their substructures and thus should also differ in their reaction kinetics.

Carbamates are generally obtained from an amine by the reaction with an adequate chloroformate or anhydride. Some of the known methods involve carbonylation of amine or nitro compounds, oxidative carbonylation of amines, the carboxylation reaction between amines and carbon dioxide, alcoholysis of urea, and carboxylation of amines involving carbonate as carbonylat. Carbamates are conventionally synthesized on industrial scale by the phosgene route [22]. Carbamates are also obtained by combining isocyanates, e.g., toluene isocyanate with compounds containing hydroxyl groups, where the carbamate groups are formed by the reaction of the alcohols or phenols with the isocyanates. This reaction can be catalyzed by aluminum chloride [23-25]. The isocyanates used in these reactions are obtained by phosgenation of the corresponding amines or the corresponding alcohols. The drawback of these processes is that they are very expensive. Furthermore, phosgene has to be used with care because of its human toxicity and ecotoxicity. 
Carbamates may also be produced by the reaction of an amine with carbonate in presence of a catalytic quantity of a Lewis acid based on zinc or tin compounds. The drawback of this process is that alcohols are always produced as byproducts and these need to be removed during the purification of the carbamates [26]. Franz et al. described a process for making methyl- $N$-phenyl carbamate from carbon monoxide, sulphur, aniline, and methanol. Very low yields are produced by this method; the yield did not exceed $25 \%$ even over extended reaction periods [27].

$\mathrm{N}$-arylcarbamates can be prepared by letting nitroaromatics react with carbon monoxide and alcohols in the presence of catalysts [28]. Thus, carbamates may be prepared by the reaction of organic nitro compounds, carbon monoxide, and hydroxyl-containing compounds in the presence of a catalysts consisting of a noble metal and a Lewis acid under essentially anhydrous conditions in the absence of hydrogen under increased pressure and at temperatures above $150{ }^{\circ} \mathrm{C}$.

Acylation provides an inexpensive and efficient way for obtaining carbamates through a synthetic process. In this paper we present an efficient synthesis of readily water-soluble carbamates containing sulfonic groups obtained from the reaction of amines with chloroformates.

\section{Results and Discussion}

Our goal was to develop a simple method for the preparation of carbamates that begins with readily available starting materials and can be carried out under mild reaction conditions while being highly efficient and economical. For our initial studies, we selected readily available methyl chloroformate, propyl chloroformate, phenyl, tolyl, and naphthalyl chloroformate as the "carbonyl source" to prepare carbamates from corresponding amines. Although the preparation of corresponding carbamates was straightforward, finding a suitable method for the preparation and purification of water-soluble carbamates containing sulfonic groups was not trivial.

Our procedure utilizes readily available aromatic and aliphatic chloroformates and the corresponding amines as reactants in $\mathrm{THF} /$ water media with sodium bicarbonate as a base (Scheme 1A). Reaction was also performed without any base (Scheme 1B). The reaction is carried out at $0{ }^{\circ} \mathrm{C}$ to prevent phenyl carbamate decomposition and is complete after all reagents are added.

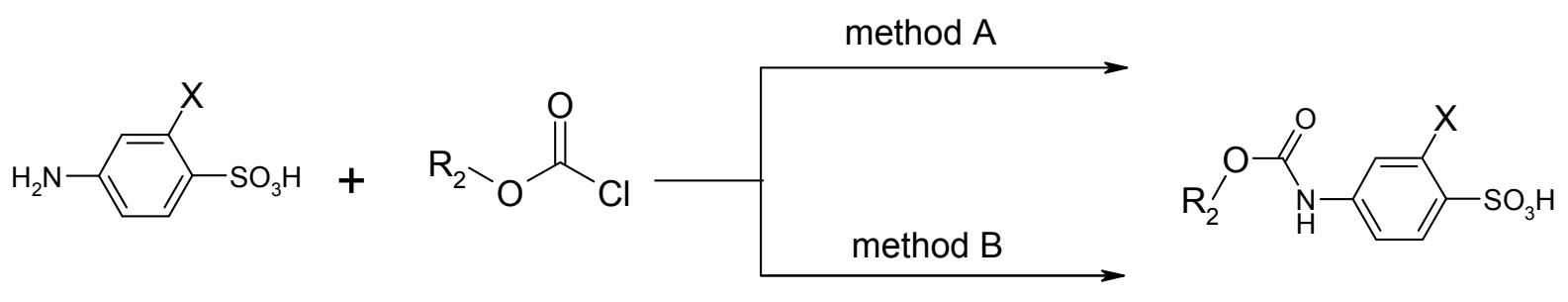

$\mathrm{X}=\mathrm{H}$ or $\mathrm{CH}_{3}$

method A: $\mathrm{NaHCO}_{3}, \mathrm{THF} / \mathrm{H}_{2} \mathrm{O}, 0^{\circ} \mathrm{C}-\mathrm{rt}$ method $\mathrm{B}: \mathrm{THF} / \mathrm{H} 2 \mathrm{O}, 0^{0} \mathrm{C}-\mathrm{rt}$

Scheme 1. Synthesis carbamates (A) with sodium bicarbonate; (B) without any bases.

The mixture was stirred at room temperature for two days. The product was isolated by solvent evaporation, and purified by recrystallization from methanol-water solution or purified by column chromatography. Yields are presented in Table 1. 
Table 1. Carbamates.

\begin{tabular}{|c|c|c|c|c|c|}
\hline \multirow{2}{*}{ Entry } & \multirow{2}{*}{ Substrate $1\left(\mathbf{R}_{1}-\mathbf{N H}_{2}\right)$} & \multirow{2}{*}{ Substrate $2\left(\mathrm{R}_{2}-\mathrm{OCOCl}\right)$} & \multirow{2}{*}{ Product $\left(\mathrm{R}_{1}-\mathrm{NHOCO}-\mathrm{R}_{2}\right)$} & \multicolumn{2}{|c|}{ Yield (\%) } \\
\hline & & & & $\mathbf{A}$ & B \\
\hline 1 & $\Longrightarrow-\mathrm{SO}_{3} \mathrm{H}$ & & & 99 & 99 \\
\hline 2 & $-\mathrm{SO}_{3} \mathrm{H}$ & & & 98 & 98 \\
\hline 3 & 1) $-\mathrm{SO}_{3} \mathrm{H}$ & & & 98 & 97 \\
\hline 4 & $\Longrightarrow-\mathrm{so}_{3} \mathrm{H}$ & & & 99 & 98 \\
\hline 5 & $-\mathrm{SO}_{3} \mathrm{H}$ & & & 98 & 96 \\
\hline 6 & & & & 98 & 98 \\
\hline 7 & $-\mathrm{SO}_{3} \mathrm{H}$ & & & 97 & 94 \\
\hline 8 & $-\mathrm{SO}_{3} \mathrm{H}$ & & & 99 & 95 \\
\hline 9 & & & & 97 & 97 \\
\hline 10 & & & & 97 & 96 \\
\hline
\end{tabular}

The solid carbamates are stable at room temperature for at least several months, making them an excellent intermediate. To determine optimal reaction conditions for the preparation of carbamates we performed experiments with varying solvents, temperatures, and reaction times. The best results are received in the method described below. Acylation of primary amines is carried out in water-THF solution using a stoichiometric amount of chloroformate followed by addition of saturated aqueous bicarbonate 
solution. The primary amine is dissolved in water and then an equivalent amount of chloroformate derivative in THF (1:1) is added dropwise under stirring. Primary amines containing protonated sulfonic groups are very poorly soluble in water and in this case must be previously heated till completely dissolved in water and after that slowly cooled to room temperature. The desired product is finally obtained by treating the reaction mixture with saturated bicarbonate solution. The products are crystallized from methanol/water solution or purified by column chromatography.

The main problem in using method A for water soluble compounds is the separation of resulting products from salts in the purification step. We tried to find an alternative method for obtaining water soluble carbamates without the presence of bicarbonate solution. It should be noted that the reaction also works very well without the presence of sodium bicarbonate. The yields of both methods are comparable. We think that the presence of sodium bicarbonate only slightly improves the yield of the reaction. Comparing the results of the two methods, we believed that the use of salt is unnecessary and only increases the cost of carbamate production. Highest yields were obtained at room temperature after reaction times of 2 days. By applying method $\mathrm{B}$ it is possible to obtain products free of inorganic salts. The results of both methods are summarized in Table 1.

According to our previously experience in the preparation of amides [29] and esters [30], we tried to use this method to obtain carbamates. A single-phase solvent system consisting of ethyl acetate as an organic solvent and triethylamine as a catalyst was used. Unfortunately, we did not observe any product formation.

We have developed an exceptionally simple, high yield, and economical procedure for the preparation of substituted carbamates from readily available amines and chloroformates. This condensation reaction can even be performed with aromatic and aliphatic groups. Not only is this approach applicable to large scale industrial syntheses, it is also applicable to the synthesis of carbamates under laboratory conditions.

\section{Experimental Section}

\subsection{General}

All chemicals, reagents, and solvents were used as received from commercial sources without further purification. ${ }^{1} \mathrm{H}-\mathrm{NMR}$ and ${ }^{13} \mathrm{C}-\mathrm{NMR}$ spectra were recorded in DMSO- $d_{6}$ on a $300 \mathrm{MHz}$ liquid state Bruker spectrometer. The splitting patterns are annotated as follows: $s$ (singlet), $d$ (doublet), $t$ (triplet), q (quartet) and $\mathrm{m}$ (multiplet). The products were also confirmed by ESI-MS (instrumentation is described in Nödler et al. [31]). Preparative column chromatography was carried out on glass columns of different sizes packed with silica gel: Merck $60(0.035-0.070 \mathrm{~mm})$.

\subsection{Synthesis}

Method A. General procedure of preparing carbamates containing sulfonic groups (in presence of sodium bicarbonate) 1-10. A solution of chloroformate $(2.0 \mathrm{mmol})$ in tetrahydrofuran $(25 \mathrm{~mL})$ was slowly added to an ice-water bath cooled solution of primary amine $(2.0 \mathrm{mmol})$ (primary amines containing sulfonic groups are very poorly soluble in cold water and must previously be heated until completely dissolved in water and after that cooled to rt.) and water solution of sodium bicarbonate 
(3.0 mmol). After the addition was complete, the ice-water bath was removed and the reaction mixture left to stir at room temperature for two days. After that, aqueous hydrochloric acid was added and the mixture was stirring for $2 \mathrm{~h}$. The solvent was evaporated to give the crude product, which was subsequently purified using column chromatography (hexane/ethyl acetate, 1:5 and then methanol).

Method B. General procedure of preparing carbamates containing sulfonic groups (without presence of sodium bicarbonate) 1-10. A solution of chloroformate $(2.0 \mathrm{mmol})$ in tetrahydrofuran $(30 \mathrm{~mL})$ was slowly added to an ice-water bath cooled solution of primary amine $(2.0 \mathrm{mmol})$ in water $(30 \mathrm{~mL})$ (primary amines containing sulfonic groups are very poorly soluble in cold water and must be previously heated till completely dissolve in water and after that cooled to rt.). After the addition was complete, the ice-water bath was removed and the reaction mixture left to stir at room temperature for two days. The solvent was evaporated to give the crude product, which was subsequently purified using column chromatography (hexane/ethyl acetate, 1:5 and then methanol).

4-[(Phenoxycarbonyl)amino]benzenesulfonic acid (1) Yield: $0.58 \mathrm{~g}(99 \%)$. White powder. ${ }^{1} \mathrm{H}-\mathrm{NMR}$ (300 MHz, DMSO-d6) $\delta$, ppm, 10.23 (s, 1H), 7.57 (d, $J=8.1 \mathrm{~Hz}, 2 \mathrm{H}), 7.44$ (d, $J=7.8 \mathrm{~Hz}, 2 \mathrm{H}), 7.39$ $(\mathrm{d}, J=7.8 \mathrm{~Hz}, 2 \mathrm{H}), 7.24$ (t, $J=7.4 \mathrm{~Hz}, 1 \mathrm{H}), 7.18$ (d, $J=7.8 \mathrm{~Hz}, 2 \mathrm{H}) ;{ }^{13} \mathrm{C}-\mathrm{NMR}\left(300 \mathrm{MHz}, \mathrm{DMSO}-d_{6}\right)$ $\delta$, ppm, 151.93, 150.52, 142.48, 139.05, 129.58, 126.48, 125.65, 121.96, 117.76. Elemental analysis for: $\mathrm{C}_{13} \mathrm{H}_{11} \mathrm{NO}_{5} \mathrm{~S}$ Calc.: C, 53.24; H, 3.78. Found: C, 53.32; H, 3.67. ESI-MS: $m / z=293$.

4-\{[(4-Methylphenoxy)carbonyl]amino\}benzenesulfonic acid (2) Yield: $0.60 \mathrm{~g}$ (98\%). White powder. ${ }^{1} \mathrm{H}-\mathrm{NMR}\left(300 \mathrm{MHz}, \mathrm{DMSO}-d_{6}\right) \delta$, ppm, 10.19 (s, 1H), 7.55 (d, $\left.J=8.5 \mathrm{~Hz}, 2 \mathrm{H}\right), 7.44$ (d, $J=8.5 \mathrm{~Hz}$, 2H), $7.20(\mathrm{~d}, J=8.5 \mathrm{~Hz}, 2 \mathrm{H}), 7.09(\mathrm{~d}, J=8.5 \mathrm{~Hz}, 2 \mathrm{H}), 2.31(\mathrm{~s}, 3 \mathrm{H}) ;{ }^{13} \mathrm{C}-\mathrm{NMR}\left(300 \mathrm{MHz}, \mathrm{DMSO}-d_{6}\right)$ $\delta$, ppm, 151.54, 148.02, 142.79, 138.49, 134.29, 129.49, 126.07, 121.38, 117.15, 20.30. Elemental analysis for: $\mathrm{C}_{14} \mathrm{H}_{13} \mathrm{NO}_{5} \mathrm{~S}$ Calc.: C, 54.72; H, 4.26. Found: C, 54.82; H, 4.36. ESI-MS: $\mathrm{m} / z=307$.

4-\{[(Naphthalen-1-yloxy) carbonyl]amino\}benzenesulfonic acid (3) Yield: $0.67 \mathrm{~g}$ (97\%). Light brown powder. ${ }^{1} \mathrm{H}-\mathrm{NMR}\left(300 \mathrm{MHz}, \mathrm{DMSO}-d_{6}\right) \delta$, ppm, $10.53(\mathrm{~s}, 1 \mathrm{H}), 8.08-7.96(\mathrm{~m}, 2 \mathrm{H}), 7.86$ (d, $J=8.0 \mathrm{~Hz}$, 2H), 7.69-7.49 (m, 5H), $7.43(\mathrm{~d}, J=7.6 \mathrm{~Hz}, 2 \mathrm{H}) ;{ }^{13} \mathrm{C}-\mathrm{NMR}\left(300 \mathrm{MHz}, \mathrm{DMSO}-d_{6}\right) \delta$, ppm, 151.59, $145.96,143.05,138.53,133.99,127.80,126.88,126.51,126.39,126.20,125.59,125.41,120.84$, 118.51, 117.31. Elemental analysis for: $\mathrm{C}_{17} \mathrm{H}_{13} \mathrm{NO}_{5} \mathrm{~S}$ Calc.: C, 59.47; H, 3.82. Found: C, 59.52; H, 3.76. ESI-MS: $m / z=343$.

4-[(Methoxycarbonyl)amino]benzenesulfonic acid (4) Yield: $0.45 \mathrm{~g}(98 \%)$. Brown powder. ${ }^{1} \mathrm{H}-\mathrm{NMR}$ (300 MHz, DMSO-d6) $\delta$, ppm, $9.67(\mathrm{~s}, 1 \mathrm{H}), 7.52(\mathrm{~d}, J=8.5 \mathrm{~Hz}, 2 \mathrm{H}), 7.39$ (d, $J=8.5 \mathrm{~Hz}, 2 \mathrm{H}), 3.66(\mathrm{~s}, 3 \mathrm{H})$; ${ }^{13} \mathrm{C}-\mathrm{NMR}(300 \mathrm{MHz}$, DMSO-d6) $\delta$, ppm, 153.70, 142.13, 139.05, 125.99, 116.84, 51.53. Elemental analysis for: $\mathrm{C}_{8} \mathrm{H}_{9} \mathrm{NO}_{5} \mathrm{~S}$ Calc.: C, 41.56; H, 3.92. Found: C, 41.72; H, 3.75. ESI-MS: $m / z=231$.

4-[(Propoxycarbonyl)amino]benzenesulfonic acid (5) Yield: $0.50 \mathrm{~g}(96 \%)$. Dark brown powder. ${ }^{1} \mathrm{H}-\mathrm{NMR}$ (300 MHz, DMSO-d6) $\delta$, ppm, $9.63(\mathrm{~s}, 1 \mathrm{H}), 7.52(\mathrm{~d}, J=8.8 \mathrm{~Hz}, 2 \mathrm{H}), 7.41(\mathrm{~d}, J=8.4 \mathrm{~Hz}, 2 \mathrm{H}), 4.01$ (t, $J=6.6 \mathrm{~Hz}, 2 \mathrm{H}), 1.65-1.56(\mathrm{~m}, 2 \mathrm{H}), 0.90(\mathrm{t}, J=7.4 \mathrm{~Hz}, 3 \mathrm{H}) ;{ }^{13} \mathrm{C}-\mathrm{NMR}\left(300 \mathrm{MHz}, \mathrm{DMSO}-d_{6}\right) \delta$, ppm, 153.17, 141.66, 139.08, 125.76, 116.62, 65.29, 21.42, 9.77. Elemental analysis for: $\mathrm{C}_{10} \mathrm{H}_{13} \mathrm{NO}_{5} \mathrm{~S}$ Calc.: C, 46.32; H, 5.05. Found: C, 46.53; H, 5.17. ESI-MS: $m / z=259$. 
3-Methyl-4-[(phenoxycarbonyl)amino]benzenesulfonic acid (6) Yield: $0.60 \mathrm{~g}$ (98\%). White powder. ${ }^{1} \mathrm{H}-\mathrm{NMR}\left(300 \mathrm{MHz}, \mathrm{DMSO}-d_{6}\right) \delta$, ppm, 9.41 (s, 1H), 7.47 (s, 1H), 7.42-7.35 (m, 4H), 7.23 (t, J=6.0 Hz, $1 \mathrm{H}), 7.20(\mathrm{~d}, J=6.0 \mathrm{~Hz}, 2 \mathrm{H}), 2.29(\mathrm{~s}, 3 \mathrm{H}) ;{ }^{13} \mathrm{C}-\mathrm{NMR}(300 \mathrm{MHz}, \mathrm{DMSO}-d 6) \delta, \mathrm{ppm}, 152.53,150.76$, $144.87,135.99,130.93,129.30,127.65,125.19,124.20,123.50,121.75,17.73$. Elemental analysis for: $\mathrm{C}_{14} \mathrm{H}_{13} \mathrm{NO}_{5} \mathrm{~S}$ Calc.: C, 54.72; H, 4.26. Found: C, 54.83; H, 4.18. ESI-MS: $m / z=307$.

3-Methyl-4-\{[(4-methylphenoxy)carbonyl]amino\}benzenesulfonic acid (7) Yield: $0.60 \mathrm{~g}$ (94\%). Brown powder. ${ }^{1} \mathrm{H}-\mathrm{NMR}\left(300 \mathrm{MHz}, \mathrm{DMSO}-d_{6}\right) \delta$, ppm, $9.37(\mathrm{~s}, 1 \mathrm{H}), 7.48(\mathrm{~s}, 1 \mathrm{H}), 7.43(\mathrm{~d}, J=8.4 \mathrm{~Hz}, 1 \mathrm{H})$, 7.37 (d, $J=8.4 \mathrm{~Hz}, 1 \mathrm{H}), 7.21$ (d, $J=8.4 \mathrm{~Hz}, 2 \mathrm{H}), 7.08$ (d, $J=8.4 \mathrm{~Hz}, 2 \mathrm{H}), 2.31$ (s, 3H), 2.28 (s, 3H); ${ }^{13} \mathrm{C}-\mathrm{NMR}\left(300 \mathrm{MHz}, \mathrm{DMSO}-d_{6}\right) \delta$, ppm, 152.62, 148.50, 144.96, 135.92, 134.24, 130.76, 129.58, 127.58, 123.56, 123.43, 121.43, 20.26, 17.69. Elemental analysis for: $\mathrm{C}_{15} \mathrm{H}_{15} \mathrm{NO}_{5} \mathrm{~S}$ Calc.: C, 56.06; H, 4.70. Found: C, 55.87; H, 4.58. ESI-MS: $m / z=321$.

3-Methyl-4-\{[(naphthalen-1-yloxy)carbonyl]amino\}benzenesulfonic acid (8) Yield: 0.68 g (95\%). Brown powder. ${ }^{1} \mathrm{H}-\mathrm{NMR}\left(300 \mathrm{MHz}, \mathrm{DMSO}-d_{6}\right) \delta$, ppm, $9.72(\mathrm{~s}, 1 \mathrm{H}), 8.03-7.98(\mathrm{~m}, 2 \mathrm{H}), 7.84(\mathrm{~d}$, $J=8.0 \mathrm{~Hz}, 1 \mathrm{H}), 7.64-7.52(\mathrm{~m}, 4 \mathrm{H}), 7.46-7.40(\mathrm{~m}, 3 \mathrm{H}), 2.36$ (s, 3H); ${ }^{13} \mathrm{C}-\mathrm{NMR}\left(300 \mathrm{MHz}, \mathrm{DMSO}-d_{6}\right)$ $\delta$, ppm, 152.57, 146.30, 145.14, 135.83, 134.04, 130.99, 127.83, 127.63, 126.99, 126.48, 126.40, 125.63, 125.32, 124.07, 123.50, 120.91, 118.47, 17.74. Elemental analysis for: $\mathrm{C}_{18} \mathrm{H}_{15} \mathrm{NO}_{5} \mathrm{~S}$ Calc.: C, 60.49; H, 4.23. Found: C, 60.37; H, 4.48. ESI-MS: $m / z=357$.

4-[(Methoxycarbonyl)amino]-3-methylbenzenesulfonic acid (9) Yield: $0.48 \mathrm{~g}$ (97\%). Brown powder. ${ }^{1} \mathrm{H}-\mathrm{NMR}\left(300 \mathrm{MHz}, \mathrm{DMSO}-d_{6}\right) \delta$, ppm, $8.80(\mathrm{~s}, 1 \mathrm{H}), 7.42$ (s, 1H), 7.38 (d, J=7.5 Hz, 1H), 7.30 (d, $J=7.5 \mathrm{~Hz}, 1 \mathrm{H}), 3.64$ (s, 3H), 2.19 (s, 3H); ${ }^{13} \mathrm{C}-\mathrm{NMR}$ (300 MHz, DMSO-d6) $\delta, \mathrm{ppm}, 154.47,144.23$, 136.26, 130.17, 127.31, 123.20, 123.10, 51.56, 17.68. Elemental analysis for: $\mathrm{C}_{9} \mathrm{H}_{11} \mathrm{NO}_{5} \mathrm{~S}$ Calc.: C, 44.08; H, 4.52. Found: C, 44.16; H, 4.69. ESI-MS: $m / z=245$.

3-Methyl-4-[(propoxycarbonyl)amino]benzenesulfonic acid (10) Yield: $0.52 \mathrm{~g}$ (96\%). Brown powder. ${ }^{1} \mathrm{H}-\mathrm{NMR}\left(300 \mathrm{MHz}, \mathrm{DMSO}-d_{6}\right) \delta$, ppm, $8.78(\mathrm{~s}, 1 \mathrm{H}), 7.46(\mathrm{~s}, 1 \mathrm{H}), 7.42(\mathrm{~d}, J=8.4 \mathrm{~Hz}, 1 \mathrm{H}), 7.32$ (d, $J=8.4 \mathrm{~Hz}, 1 \mathrm{H}), 4.01(\mathrm{t}, J=6.6 \mathrm{~Hz}, 2 \mathrm{H}), 2.20(\mathrm{~s}, 3 \mathrm{H}), 1.66-1.57(\mathrm{~m}, 2 \mathrm{H}), 0.91(\mathrm{t}, J=7.4 \mathrm{~Hz}, 3 \mathrm{H})$;

${ }^{13} \mathrm{C}-\mathrm{NMR}\left(300 \mathrm{MHz}, \mathrm{DMSO}-d_{6}\right) \delta$, ppm, 154.52, 143.90, 136.92, 130.63, 127.64, 124.35, 123.51, 65.85, 22.02, 17.83, 10.30. Elemental analysis for: $\mathrm{C}_{11} \mathrm{H}_{15} \mathrm{NO}_{5} \mathrm{~S}$ Calc.: C, 48.34; H, 5.53. Found: C, 48.13; H, 5.36. ESI-MS: $m / z=273$.

\section{Conclusions}

We have developed a very simple, inexpensive, nontoxic, and environmentally friendly method for the preparation of carbamates containing sulfonic groups. The presence of the $\mathrm{SO}_{3} \mathrm{H}$ group in all synthesized carbamates ensures their good water solubility as their respective salts and thus their application as tracers in geo-reservoirs. In particular, there is not much information related to the synthesis of readily water-soluble carbamates. We strongly feel that this study will find numerous applications even beyond tracers for geothermal applications. 


\section{Supplementary Materials}

Supplementary materials can be accessed at: http://www.mdpi.com/1420-3049/20/04/6856/s1.

\section{Acknowledgments}

The presented study was funded by the German Ministry of Environment (BMU) (promotional reference No. 0325417, Reaktherm). This support is gratefully acknowledged. We also acknowledge support from the German Research Foundation and the Open Access Publication Funds of Göttingen University.

\section{Author Contributions}

KRI and TL designed research; KRI, KN performed research and analyzed the data; KRI and TL wrote the paper. All authors read and approved the final manuscript.

\section{Conflicts of Interest}

The authors declare no conflict of interest.

\section{References}

1. Kim, M.K.; Park, K.S.; Yeo, W.S.; Choo, H.; Chong, Y. In vitro solubility, stability and permeability of novel quercetin-amino acid conjugates. Bioorg. Med. Chem. 2009, 17, 1164-1171.

2. Mulholland, P.J.; Ferry, D.R.; Anderson, D.; Hussain, S.A.; Young, A.M.; Cook, J.E.; Hodgkin, E.; Seymour, L.W.; Kerr, D.J. Pre-clinical and clinical study of QC12, a water-soluble, pro-drug of quercetin. Ann. Oncol. 2001, 12, 245-248.

3. Ninomiya, M.; Tanaka, K.; Tsuchida, Y.; Muto, Y.; Koketsu, M.; Watanabe, K. Increased bioavailability of tricin-amino acid conjugates via a prodrug approach. J. Med. Chem. 2011, 54, 1529-1536.

4. Rubio-Aliaga, I.; Daniel, H. Mammalian peptide transporters as targets for drug delivery. Trends Pharmacol. Sci. 2002, 23, 434-440.

5. Cao, F.; Guo, J.X.; Ping, Q.N.; Liao, Z.G. Prodrugs of scutellarin: ethyl, benzyl and $N, N$-diethylglycolamide ester synthesis, physicochemical properties, intestinal metabolism and oral bioavailability in the rats. Eur. J. Pharm. Sci. 2006, 29, 385-393.

6. Labanca, R.A.; Gloria, M.B.A. Spectrophotometric determination of urea in sugar cane distilled spirits. J. Agric. Food Chem. 2008, 56, 5211-5215.

7. Esti, M.; Fidaleo, M.; Moresi, M.; Tamborra, P. Modeling of urea degradation in white and rosé wines by acid urease. J. Agric. Food Chem. 2007, 55, 2590-2596.

8. Lachenmeier, D.W.; Lima, M.C.P.; Nobrega, I.C.C.; Pereira, J.A.P.; Kerr-Correa, F.; Kanteres, F.; Rehm, J. Cancer risk assessment of ethyl carbamate in alcoholic beverages from Brazil with special consideration to the spirits cachaça and tiquira. BMC Cancer 2010, 10, 266-280.

9. Araque, I.; Gil, J.; Carrete, R.; Bordons, A.; Reguant, C. Detection of arc genes related with the ethyl carbamate precursors in wine lactic acid bacteria. J. Agric. Food Chem. 2009, 57, 1841-1847. 
10. Stokes, K.; McVenes, R.; Anderson, J. M. Polyurethane elastomer biostability. J. Biomater. Appl. 1995, 9, 321-354.

11. Choi, T.; Weksler, J.; Padsalgikar, A.; Runt, J. Novel hard-block polyurethanes with high strength and transparency for biomedical applications. J. Biomater. Sci. Polym. Ed. 2011, 22, 973-980.

12. Szycher, M. Szycher's Handbook of Polyurethanes; CRC Press: Boca Raton, FL, USA, 1999.

13. Hirsch, D.J.; Bergen, P.; Jindal, K.K. Polyurethane catheters for long-term hemodialysis access. Artif. Organs 1997, 21, 349-354.

14. Browning, M.B.; Dempsey, D.; Guiza, V.; Becerra, S.; Rivera, J.; Russell, B.; Clubb, F.; Miller, M.; Fossum, T.; Dong, J.F.; et al. Multilayer vascular grafts based on collagen-mimetic proteins. Acta Biomater. 2012, 8, 1010-1021.

15. Smith, S.L.; Ash, H.E.; Unsworth, A. A tribological study of UHMWPE acetabular cups and polyurethane compliant layer acetabular cups. J. Biomed. Mater. Res. Part B 2000, 53, 710-716.

16. McCoy, T.J.; Wabers, H.D.; Cooper, S.L. Series shunt evaluation of polyurethane vascular graft materials in chronically AV-shunted canines. J. Biomed. Mater. Res. 1990, 24, 107-129.

17. Fernandez, M.; Pico, Y.; Manes, J. Determination of carbamate residues in fruit and vegetables by matrix solid-phase dispersion and liquid chromatography-mass spectrometry. J. Chromatogr. A 2000, 871, 43-56.

18. US Environmental Protection Agency. National Survey of Pesticides in Drinking Water Wells, Phase II Report; EPA 570/9-91-020, National Technical Information Service; US Environmental Protection Agency: Springfield, VA, USA, 1992.

19. Directive 2006/118/EC of the European Parliament and of the Council of 12 December 2006 on the protection of groundwater against pollution and deterioration. Off. J. Eur. Union 2006, L372, $19-31$.

20. Nottebohm, M.; Licha, T.; Sauter, M. Tracer design for tracking thermal fronts in geothermal reservoirs. Geothermics 2012, 43, 37-44.

21. Tester, J.W.; Robinson, B.A.; Ferguson, J.H. The theory and selection of chemically reactive tracers for reservoir thermal capacity production. In Proceedings of the Twelfth Workshop on Geothermal Reservoir Engineering, Stanford University, Stanford, CA, USA, 20-22 January 1987; SGP-TR-109.

22. Houben-Weyl. In Methods of Organic Chemistry; Georg Thieme Publishers: Stuttgart, Germany, 1952; Volume 8, pp. 137, 120 and 101.

23. Spegazzini, N.; Siesler, H.W.; Ozak, Y. Modeling of isomeric structure of diphenyl urethane by FT-IR spectroscopy during synthesis from phenylisocyanate and phenol as an inverse kinetic problem. J. Phys. Chem. A 2011, 115, 8832-8844.

24. Spegazzini, N.; Siesler, H.W.; Ozak, Y. Sequential identification of model parameters by derivative double two-dimensional correlation spectroscopy and calibration-free approach for chemical reaction systems. Anal. Chem. 2012, 84, 8330-8339.

25. Hutchby, M.; Houlden, C.E.; Ford, J.G.; Tyler, S.N.G.; Gagn, M.R.; Lloyd-Jones, G.C.; Booker-Milburn, K.I. Hindered ureas as masked isocyanates: Facile carbamoylation of nucleophiles under neutral conditions. Angew. Chem. Int. Ed. 2009, 48, 8721-8724.

26. Gurgiolo, A.E.; Jackson, L. Preparation of Carbamates from Aromatic Amines and Organic Carbonates. U.S. Patent 4,268,683, 19 May 1981. 
27. Franz, R.A.; Applegath, F.; Morriss, F.V.; Breed, L.W. A new synthesis of ureas. The preparation of methyl- $N$-phenylurethane from carbon monoxide, sulfur, aniline, and methanol. J. Org. Chem. 1963, 28, 585-586.

28. Putnam Bennett, R.; Hardy, W.B. Process of Producing Urethanes. U.S. Patent 3,467,694, 16 September 1969.

29. Idzik, K.R.; Noedler, K.; Licha, T. Efficient synthesis of readily water soluble amides containing sulfonic groups. Synth. Commun. 2014, 44, 133-140.

30. Idzik, K.R.; Noedler, K.; Friedrich, M.; Licha, T. Efficient synthesis and reaction kinetics of readily water soluble esters containing sulfonic groups. Molecules 2014, 19, 21022-21033.

31. Nödler, K.; Licha, T.; Bester, K.; Sauter, M. Development of a multi-residue analytical method, based on liquid chromatography-tandem mass spectrometry, for the simultaneous determination of 46 micro-contaminants in aqueous samples. J. Chromatogr. A 2010, 1217, 6511-6521.

Sample Availability: Samples of the compounds are not available from the authors.

(C) 2015 by the authors; licensee MDPI, Basel, Switzerland. This article is an open access article distributed under the terms and conditions of the Creative Commons Attribution license (http://creativecommons.org/licenses/by/4.0/). 